
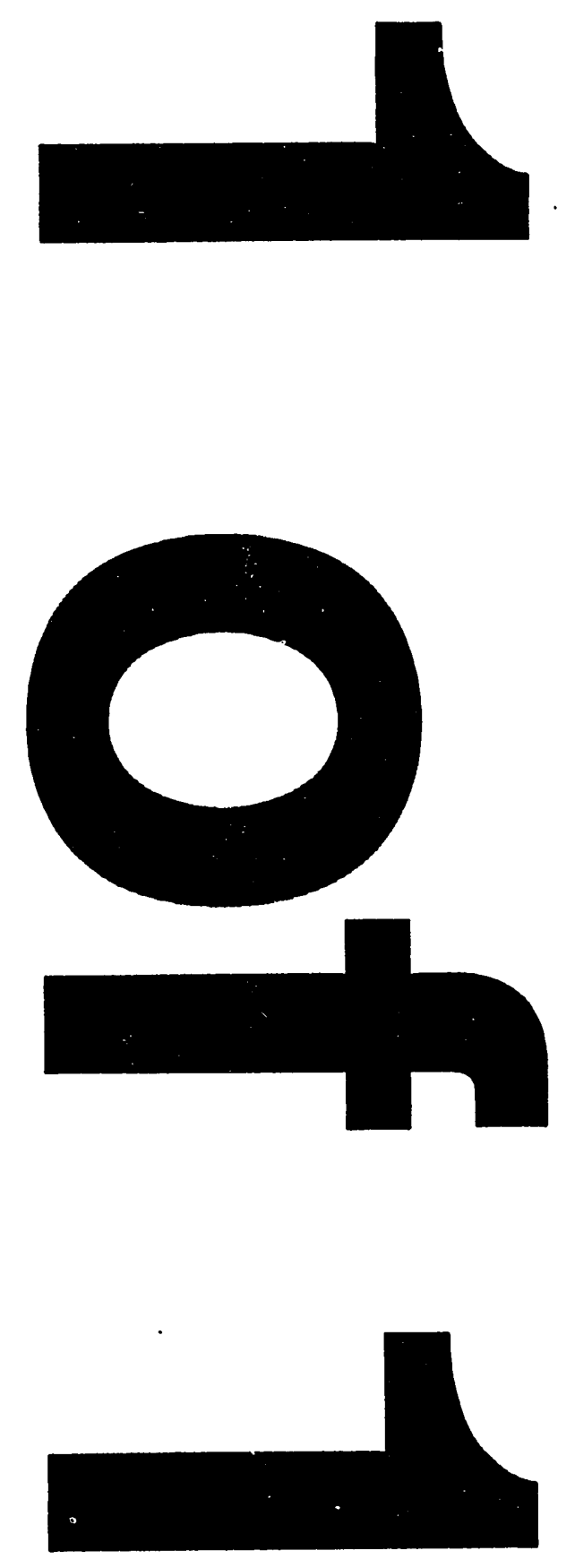


\title{
F/H SEEPAGE BASIN GROUNDWATER INFLUENT, EFFLUENT, PRECIPITATED SLUDGE CHARACTERIZATION TASK TECHNICAL PLAN
}

by

J. L. Siler

Savannah River Site

Aiken, South Carolina 29808

\section{DISCLAIMER}

\begin{abstract}
This report was prepared as an account of work sponsored by an agency of the United States Government. Neither the United States Government nor any agency thereof, nor any of their employees, makes any warranty, express or implied, or assumes any legal liability or responsiemployes, makccuracy, completeness, or usefulness of any information, apparatus, product, or bility for the accuracy, completeness, or usefulness of infringe privately owned rights. Referprocess disclosed, or represents that its use would process, or service by trade name, trademark, ence herein to any specific commercial product, process, or service by trade name, trademark, manufacturer, or otherwise does not necessarily constitute or imply its endorsement, recommendation, or favoring by the United States Government or any agency theref. The vews and opinions of authors expressed herein do not necessarily state or reflect those of the United States Government or any agency thereof.
\end{abstract}

\section{DOE Contract No. DE-AC09-89SR18035}

This paper was prepared in connection with work done under the above contract number with the U. S.

Department of Energy. By acceptance of this paper, the publisher andor recipient acknowledges the U. S. Government's right to retain a nonexclusive, royalty-free license in and to any copyright covering this paper, along with the right to reproduce and to authorize others to reproduce all or part of the copyrighted paper. 


\section{DISCLAIMER}

This report was prepared as an account of work sponsored by an agency of the United States Government. Neither the United States Government nor any agency thereof, nor any of their employees, makes any wamanty, express or implied, or assumes any legal liability or responsibility for the accuracy. completeness, or usefulness of any information, apparatus, product, or process disclosed, or represents that its use would not infringe privately owned rights. Reference herein to any specific commercial product, process, or service by trade name, trademark, manufacturer, or otherwise does not necessarily constitute or imply its endorsement, recommendation, or favoring by the United States Government or any agency thereof. The views and opinions of authors expressed herein do not necessarily state or reflect those of the United States Government or any agency thereof.

This report has been reproduced directly from the best available copy.

Available to DOE and DOE contractors from the Office of Scientific and Technical Information, P. O. Box 62, Oak Ridge, TN 37831; prices available from (615) 576-8401.

Available to the public from the National Technical Information Service. U. S. Deparment of Commerce, 5285 Port Royal Rd., Springfield, VA 22161 
WESTINGHOUSE SAVANNAH RIVER COMPANY

SAVANNAH RIVER TECHNOLOGY CENTER

\author{
WSRC-RP-93-941, Rev. 1 \\ Keywords: F/H Seepage Basin \\ Facility, Filtration, \\ Groundwater Remediation \\ October 29, 1993 \\ CC: W. L. Tamosaitis, 773A \\ J. P. Bibler, 773A \\ P. E. Lowe, 773-42A \\ L. M. Nelson, 773-43A \\ R. N. Strom, 773-42A \\ J. A. Adams, $\mathrm{CCC} 4$ \\ B. T. Butcher, $\mathrm{CCC} 4$ \\ M. E. Gorden, $\operatorname{CCC} 4$ \\ C. M. Lewis, $\operatorname{CCC} 4$ \\ B. A. Hamm, CCC4 \\ B. G. Schappell, $\operatorname{CCC} 4$ \\ S. M. Serkiz, CCC 4 \\ M. R. Welty, $\operatorname{cCC} 4$ \\ SRTC Records (4)
}

TO: R. H. Hsu, 773-43A

From: J. L. Siler, 773-43A\&2S

\title{
E/H SFEPAGE BASTN GROUNDTATER INELUENT, FFFIUFNT, AND RRECIPITATED SLCDGE CHARACTERIZATION TASK TECHNICAL PIAN(U)
}

\subsection{INTRODUCTION}

The Environmental Restoration (ER) Department is responsible for environmental remediation projects on Site. ER requested Interim Waste Technology section (IWTS) to conduct a treatability study in support of the development of a remediation system which would reduce the contaminant levels in groundwater removed from the aquifers in the vicinity of the $\mathrm{F} / \mathrm{H}$ seepage basins and southwest corner of the Mixed Waste Management Facility (MWMF). This work 
R. H. Hsu

WSRC-RP-93-0941, Rev. 1

Page 2

October 29,1993

was discussed in reports by M. R. Poirier (1992) and J. P. Bibler (1991). Poirier's work concluded that neutralization followed by ceramic micro filtration reduced the contaminant levels sufficiently. $\mathrm{pH}$ adjustment with $\mathrm{NaOH}$ to 6-8 used in conjunction with aluminum sulfate resulted in the greatest number of ions being precipitated.

The project has been re-baselined (following negotiations with SCDHEC) from one central treatment system for both areas to two smaller systems to treat $F$ and $H$ Areas separately. The two systems will have smaller capacities, but will be able to come online quicker.

The original work done by Poirier (1992) and Bibler (1991) dealt with a composite groundwater stream from $F$ and $H$ Area. No data has been generated on the precipitate characteristics of segregated streams. This need was the driving force for this task plan.

The purpose of this task is to determine whether precipitated sludge generated from the proposed remediation system will be hazardous as defined by RCRA. Several contaminants, such as lead and mercury, are above the groundwater protection standards (GWPS). The presence of radionuclides and other contaminants in the sludge does not present a problem, provided that the sludge can pass the Toxicity Characteristic Leaching Procedure (TCLP) test. Other goals that will be pursued in the study will be outlined in Section 3.0 .

A final treatment technology has not been established for the rebaseline project. This study has been developed in such a manner as to cover the possible range of treatment options that may be used. A 0.45 Millipore filter disk will be used to conduct the filtration. This filter option should provide the best laboratory performance for the quantity of well water to be sampled, treated, and analyzed. Aluminum sulfate will be used as a flocculant as recommended by Bibler (1991).

Wells for this sludge study are listed in Table 1.

Table 1. Groundwater Wells to be used for the sludge Study.

EArea
FSB 78
FSB $93 D$
FSB $97 D$
FSB $98 D$
FSB $109 D$

H Area

HSB 101D

HSB $104 \mathrm{D}$

HSB $105 \mathrm{D}$

HSB $107 \mathrm{D}$

HSB $108 \mathrm{D}$

This well selection is representative of the metal plumes and will 
R. H. Hsu

WSRC-RP-93-0941, Rev. 1

Page 3

October 29, 1993

provide appropriate worst-case data.

An additional technology will be evaluated during this testing, if time permits. Reverse osmosis (RO) will be evaluated on the two composite samples. A lab-scale unit is avaliable in SRTC to study this problem.

\subsection{TASK DEIIVERABIES}

\section{Beports}

Reports documenting the results of this research project will be compiled as internal WSRC reports. These reports will be received by ER and other appropriate organizations. The reports will be issued a WSRC-RP-\#, and will be given permanent retention status.

\subsection{TASK REOUIRFYFNTS}

The requirements of this task are to:

- characterize the extracted and treated groundwater

- determine decontamination factors for the pH adjusted filtration, with and without alum

- determine whether the precipitated groundwater sludge is hazardous by performing the TCLP test (or approved analog) on the sludge

- perform a material balance on the influent, sludge, and effluent

- compare the sludge characteristics to the Waste Acceptance Criteria of the E-Area Vaults

- determine if the solids generated from drying the sludge will present a dusting problem

- compare (if equipment permits) analytical data generated on Site using inductively coupled plasma mass spectrophotometrometer (ICP-MS) to the off-Site EPA-approved methods

- collect groundwater samples for a settling experiment which will represent a shutdown condition of the treatment units (actual experiment to be performed under separate Task Technical Plan)

- perform a radionuclide characterization of the sludge so that shielding calculations for the $B-12$ containers can be performed 
R. H. Hsu

WSRC-RP-93-0941, Rev. 1

Page 4

October 29, 1993

- evaluate the use of RO for removing salts and metals from the composite groundwater samples. This work will be performed as long as results from the filtration work are not impacted

\section{0 TASK PREREOUISITES}

Task Technical Plan

This task plan will be reviewed by ER. IWTS, ADS, AND ER will approve this Task Technical Plan.

\section{Task OA PIan}

IWTS will generate a Task QA Plan to support this Task Technical Plan. IWTS and SRTC-QS will approve the Task QA Plan. No special training is necessary. Chain of custody will be addressed in the Task QA Plan.

\section{Procedure (s)}

IWTS will generate the required procedure(s) for operation of the test equipment. IWTS will approve the procedure(s).

\section{5 . 0 TASK ACTIVITIFS AND DESCRIPTION}

\section{Experimental Precedure eutline}

The experimental studies to be conducted will be performed in laboratory B-122 for the actual groundwater. The test solution will be actual wellwater from the $F / H$ Area wells. All samples will be submitted for analysis in duplicate to SRTC and offsite laboratories. Listed below is the experimental procedure (see Figure 1 for a schematic representation).

Step 1. PROCURE WELL WATER - Individual well samples from H area will be obtained from the wells designated in Table 1 . The samples will be taken by EMS, and then given to IWT TAs at the work site. IWT-TAs will record the actual process and information on all personnel involved in the sampling process in a logbook. Approximately five gallons of groundwater will be withdrawn from each well. The exact amount may vary once the actual sampling and testing begin. Containers will be provided by SRTC.

Step 2. COMPOSITE SAMPLE PREPARATION AND CHARACTERIZATION - The IWT TAs will generate the composite samples while in the field and place the samples in all appropriate containers for analysis. An example of "appropriate container" would be 
R. H. Hsu

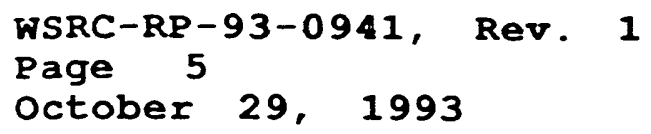

zero-head-space vials for VoCs analyses. The IWT TAs will disinfect the composite samples with chlorine. Ar adequate portion of the composite will be submitted for Total Solids (TS), Total Dissolved Solids (TDS), and Total Suspended Solids (TSS). Adequate portions of the composite sample will also be submitted for analysis to test for specific constituents as outlined in Table 2 .

Step 3. PROPORTION COMPOSITE SAMPLE - Split each composite into four parts. One part will consist of 4 gallons of groundwater to be used in the settling experiment to be defined under another task plan. The remainder of the volume of the compos:-es will be equally divided into three subcomposites. Each of these subcomposites will be used in Steps $4 \mathrm{a}, 4 \mathrm{~b}$, and $4 \mathrm{c}$.

Step 4. EXPERIMENTAL WORK - Each of the three equally divided subcomposites generated in step 3 will undergo a specific treatment. The treatments are as follows:

a. One subcomposite will undergo aluminum sulfate addition, $\mathrm{pH}$ adjustment, flocculation, and filtration.

b. One subcomposite will undergo $\mathrm{pH}$ adjustment and filtration.

c. One subcomposite will be spiked with designated amounts of TCLP constituents and then treated by filtration and $\mathrm{pH}$ adjustment.

Step 5.EFFIUENT CHARACTERIZATION - Adequate portions of each effluent generated in steps $4 \mathrm{a}, 4 \mathrm{~b}$, and $4 \mathrm{c}$ will be submitted for analysis for TS, TDS, and TSS. Adequate portions of the composite sample will also be submitted for analysis to test for specific constituents as outlined in Table 2 .

Step 6. SOLIDS CHARACTERIZATION - Extract approximately $1.5 \mathrm{~g}$ of solids collected in steps $4 a, b$, and $c$ using a modified TCLP procedure (ADS performs this test - similar to the TCLP procedure). The extracted solution is then sent to the off-site vendor for TC (Toxicity Characteristic) metals analysis (ADS handles the contract).

Step 7. RO TESTING - RO will be evaluated on the composite sam es to determine the removal efficiency for the RCRA metals and salts. This testing will not impact the filtration work.

Steps 1 through 7 should be repeated for designated wells in $F$ Area. 
R. H. Hsu

WSRC-RP-93-0941, Rev. 1

Page 6

October 29, 1993

Figure 1. Diagram of Experimental Protocol

STEP 1 PROCURE INDIVIDUAL WELL SAMPLES

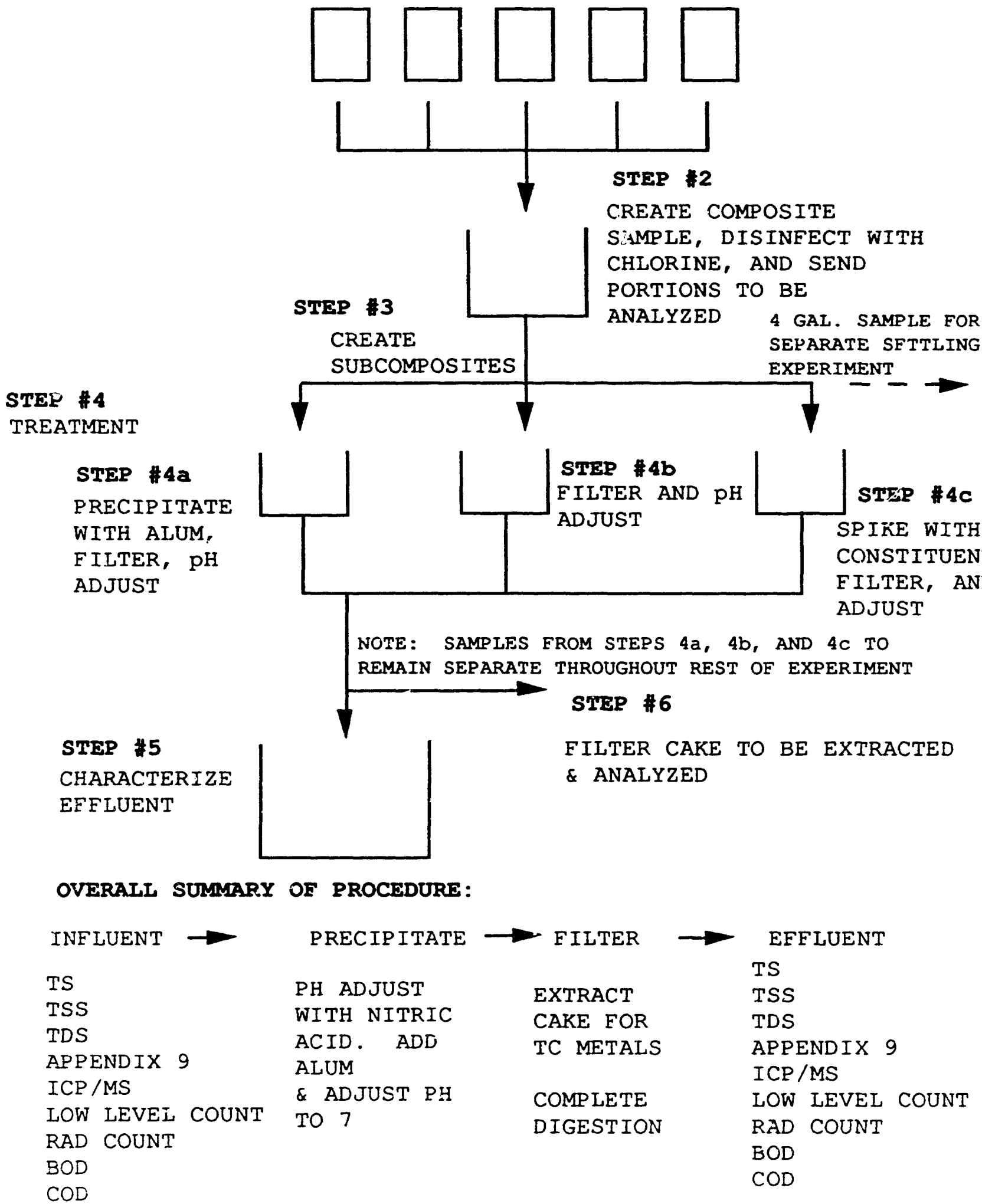


R. H. Hsu

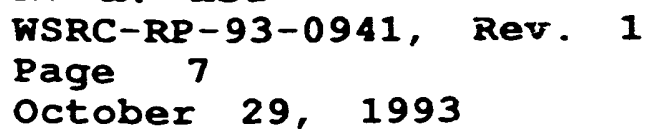

ANAIYSES TO BE PERFORMED - The characterization to be performed on the composite samples, filtrates, and solids (in addition to the tests described in steps 3,5 , and 6 ), involves:
A. Appendix 9 analyses (offsite - certified)
B. ICP/MS (SRTC -- if possible - not certified)
C. off-Site EPA-approved method for TCLP metals analyses
D. low-level counting (SRTC - certified)
E. radionuclide content (offsite - certified)
F. biological oxygeñ demand (BOD) [offsite - certified]
G. chemical oxygen demand (COD) [offsite - certified]

Table 2 provides deiails as to what analyses will be used to detect each constituent, where the analyses will be conducted, and at the appropriate step the analyses will occur.

NOTE: Duplicate samples will be submitted for all analyses.

\section{Experimental Iogistias}

These experiments will be conducted by J. L. Siler and IWT technicians using procedures/instructions. Data collected will be entered on data sheets by the technicians and also in a laboratory notebook by J. L. Siler.

The work with actual groundwater will be performed in the 773-A, B-122 laboratory. All onsite samples will be analyzed by ADS per QA Implementation Manual, 1231-3. Off-Site analyses will be handled by ADS.

\subsection{EXPFRIMFNTAI ACTIVITIES}

The following preliminary schedule outlines the experimental plan to be conducted:

1. Obtain samples from selected wells (August).

2. Perform precipitation experiments (August and September).

3. Report analytical results (February 1, 1994).

\section{CHANGES TO THE TASK TECHNICAT PIAN}

Minor changes to this task technical plan will be noted in laboratory noteiook \#WSRC-NB-90-256. Major revisions will result in a revised task technical plan.

\subsection{REEERENCES}

Bibler, J. P., "Treatability Studies on F/H-Area Groundwater Composite(U)", WSRC-RP-91-1030, October 29,1991. 
R. H. Hs

WSRC-RP-93-0941, ReV. 1

Page 8

October 29, 1993

Poitier, M. R., "Testing of Filter Technologies for the Remedialion of $\bar{R} / \mathrm{H}$ Area Seepage Basin Groundwater", WSRC-RP-92-597, May 4. 1992 . 
R. H. Hsu

WSRC-RP-93-0941, Rev. 1

Page 9

October 29, 1993

Table 2. Constituents to be Analyzed

\begin{tabular}{|c|c|c|c|}
\hline Constituent & Analysis & SRTC/Offsite & step \\
\hline \multicolumn{4}{|l|}{ organics } \\
\hline Benzene & GC/MS & both & $2,5,6$ \\
\hline Chloroethylene & GC/MS & both & $2,5,6$ \\
\hline Dichloroethylene & GC/MS & both & $2,5,6$ \\
\hline Dissolved organic carbon & Filter then TC & both & $2,5,6$ \\
\hline Methylene chloride & GC/MS & both & $2,5,6$ \\
\hline Phenols & GC/MS & both & $2,5,6$ \\
\hline Tetrachloroethylene & GC/MS & both & $2,5,6$ \\
\hline Total Organic Carbon & TC/IC & both & $2,5,6$ \\
\hline Trichloroethylene & GC/MS & both & $2,5,6$ \\
\hline Trichlorflouromethane & GC/MS & both & $2,5,6$ \\
\hline Bis (2-ethyl (hexyl)) Phlalate & GC/MS & both & $2,5,6$ \\
\hline \multicolumn{4}{|l|}{ Metals } \\
\hline Aluminum & ICP /MS \& AppII & both & $2,5,6$ \\
\hline Antimony & ICP /MS \& AppIX & both & $2,5,6$ \\
\hline Arsenic & ICP /MS \& AppIX & both & $2,5,6$ \\
\hline Barium & ICP/MS \& AppIX & both & $2,5,6$ \\
\hline Cadmium & ICP /MS \& AppIX & both & $2,5,6$ \\
\hline Calcium & ICP /MS \& AppIX & both & $2,5,6$ \\
\hline Chromium & ICP /MS \& AppIX & both & $2,5,6$ \\
\hline Cobalt & ICP /MS \& AppIX & both & $2,5,6$ \\
\hline Copper & ICP /MS \& AppIX & both & $2,5,6$ \\
\hline Cyanide & ICP /MS \& AppIX & both & $2,5,6$ \\
\hline Dissolved inorganic carbon & Eiliter then IC & both & $2,5,6$ \\
\hline Mercury & ICI/MS \& AppIX & both & $2,5,6$ \\
\hline Lead & IC $2 / \mathrm{MS} \&$ AppIX & both & $2,5,6$ \\
\hline Manganese & ICP/MS \& AppIX & both & $2,5,6$ \\
\hline Magnesium & ICP /MS \& AppIX & both & $2,5,6$ \\
\hline Nickel & ICP /MS \& AppIX & both & $2,5,6$ \\
\hline Chloride & IC \& AppIX & both & $2,5,6$ \\
\hline Eluoride & IC \& AppIX & botn & $2,5,6$ \\
\hline Iron & ICP /MS \& AppIX & both & $2,5,6$ \\
\hline Nitrate & IC \& AppIX & both & $2,5,6$ \\
\hline Potassium & $A A \& A p p I X$ & both & $2,5,6$ \\
\hline Selenium & ICP /MS \& AppIX & both & $2,5,6$ \\
\hline Silver & ICP /MS \& AppIX & both & $2,5,6$ \\
\hline Silica & ICP /MS \& AppIX & both & $2,5,6$ \\
\hline Sodium & ICP /MS \& AppIX & both & $2,5,6$ \\
\hline Sulfate & IC \& AppIX & both & $2,5,6$ \\
\hline $\mathrm{pH}$ & $\mathrm{pH}$ meter & both & $2,5,5$ \\
\hline Thallium & IC \& AppIX & both & $2,5,6$ \\
\hline
\end{tabular}


R. H. Hsu

HSRC-RP-93-0941, Rev. 1

Page 10

October 29, 1993

\begin{tabular}{|c|c|c|c|}
\hline Total Phosphates & EPA method & both & $2,5,6$ \\
\hline Tributyl phosphate & Oil \& Grease & SRTC & $2,5,6$ \\
\hline Vanadium & ICP /MS \& AppIX & both & $2,5,6$ \\
\hline Zinc & ICP/MS \& AppIX & both & $2,5,6$ \\
\hline Tin & ICP /MS \& AppIX & both & $2,5,6$ \\
\hline \multicolumn{4}{|l|}{ Radionuclides } \\
\hline Total Uranium & EPA method & Off & $2,5,6$ \\
\hline $\mathrm{U}-233$ & EPA method & Off & $2,5,6$ \\
\hline $\mathrm{U}-234$ & EPA method & off & $2,5,6$ \\
\hline $\mathrm{U}-235$ & EPA method & Off & $2,5,6$ \\
\hline $\mathrm{U}-236$ & EPA method & off & $2,5,6$ \\
\hline $\mathrm{U}-238$ & EPA method & Off & $2,5,6$ \\
\hline $\mathrm{Pu}-238$ & EPA method & Off & $2,5,6$ \\
\hline $\mathrm{Pu}-239$ & EPA method & Off & $2,5,6$ \\
\hline $\mathrm{Pu}-240$ & EPA method & Off & $2,5,6$ \\
\hline $\mathrm{Pu}-241$ & Calculations & SRTC & $2,5,6$ \\
\hline $\mathrm{Pu}-242$ & Calculations & SRTC & $2,5,6$ \\
\hline Tritium $(\mathrm{H}-3)$ & EPA method & Off & $2,5,6$ \\
\hline $\mathrm{Ra}-226$ & EPA method & Off & $2,5,6$ \\
\hline $\mathrm{Ra}-228$ & EPA method & Off & $2,5,6$ \\
\hline Total Ra & EPA method & Off & $2,5,6$ \\
\hline$S r-90$ & EPA method & Off & $2,5,6$ \\
\hline$I-129$ & EPA method & Off & $2,5,6$ \\
\hline Cs-137 & EPA method & Off & $2,5,6$ \\
\hline $\mathrm{Co}-60$ & EPA method & Off & $2,5,6$ \\
\hline $\mathrm{Cu}-244$ & EPA method & Off & $2,5,6$ \\
\hline TC-99 & EPA method & Off & $2,5,6$ \\
\hline Th-228 & EPA method & off & $2,5,6$ \\
\hline$T h-232$ & EPA method & Off & $2,5,6$ \\
\hline $\mathrm{Th}-234$ & EPA method & Off & $2,5,6$ \\
\hline$A m-241$ & EPA method & Off & $2,5,6$ \\
\hline $\mathrm{Am}-243$ & Calculations & SRTC & $2,5,6$ \\
\hline$C-14$ & EPA method & Off & $2,5,6$ \\
\hline $\mathrm{Nb}-94$ & EPA method & Off & $2,5,6$ \\
\hline $\mathrm{Ni}-59$ & EPA method & Off & $2,5,6$ \\
\hline $\mathrm{Np}-237$ & EPA method & Off & $2,5,6$ \\
\hline $\mathrm{Se}-79$ & EPA method & Off & $2,5,6$ \\
\hline $\mathrm{Rb}-87$ & EPA method & Off & $2,5,6$ \\
\hline Gross alpha & EPA method & Off & $2,5,6$ \\
\hline Gross nonvolatile beta & EPA method & Off & $2,5,6$ \\
\hline $\mathrm{Cm}-243$ & EPA method & Off & $2,5,6$ \\
\hline$U-233$ & EPA method & Off & $2,5,6$ \\
\hline $\mathrm{Ac}-228$ & EPA method & Off & $2,5,6$ \\
\hline Sr-89 & Calculations: & SRTC & $2,5,6$ \\
\hline$T h-230$ & EPA method & off & $2,5,6$ \\
\hline $\mathrm{Cm}-242$ & EPA method & Off & $2,5,6$ \\
\hline
\end{tabular}


R. H. Hsu

WSRC-RP-93-0941, Rev. 1

Page 11

October 29, 1993

\begin{tabular}{|l|l|l|l|}
\hline Cm-243/244 & ERA method & Off & $2,5,6$ \\
\hline Cm-246 & EPA method & Off & $2,5,6$ \\
\hline Count pre-digested solids & EPA method & SRTC & $2,5,6$ \\
\hline Other & & & \\
\hline Solids content & & & \\
\hline Particle size distr. & TS, TDS, TSS & SRTC & $2,5,6$ \\
\hline BOD & Size Analyzer & SRTC & $2,5,6$ \\
\hline COD & EPA method & Off & $2,5,6$ \\
\hline $\begin{array}{l}\text { Determine oxidation state } \\
\text { of chronium }\end{array}$ & EPA method & Off & $2,5,6$ \\
\hline Modified TCLP & ACA method & Off & $2,5,6$ \\
\hline
\end{tabular}


R. H. Hsu

HSRC-RP-93-0941, Rev. 1

Page 12

October 29, 1993

\section{REVIFEA AND APPROVATS}

Reviewed by:

M.R. Weety

M. R. Welf, Project Engineer, ER Date

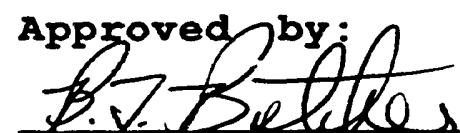

B. T. Butcher, Manager, ERG-Central Date

$\frac{R \cdot \text { A A w }}{\text { R. H. Hsu, Manager, IWTS }} \frac{10 / 29 / 93}{\text { Date }}$
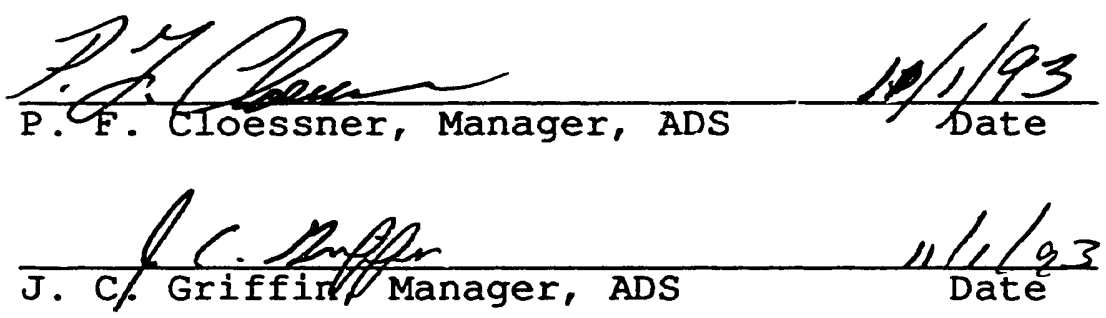

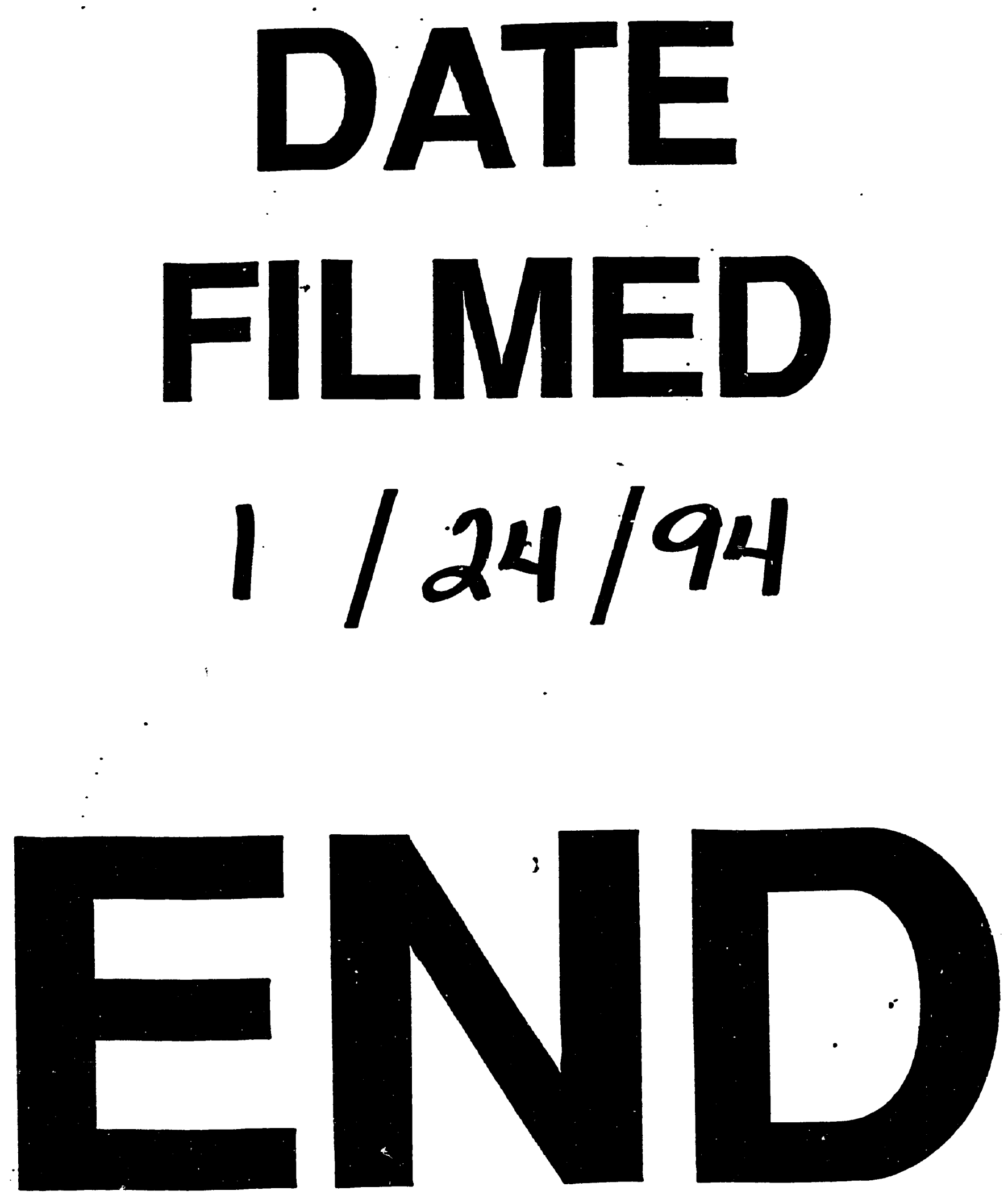